$\mathrm{Oz}$

$1-1-2018$

\title{
The Photos You Don't Take, Stay with You Forever
}

Driely S.

Follow this and additional works at: https://newprairiepress.org/oz

Part of the Architecture Commons

(c) (1) $\Theta \Theta$

This work is licensed under a Creative Commons Attribution-Noncommercial-No Derivative Works 4.0 License.

\section{Recommended Citation}

S., Driely (2018) "The Photos You Don't Take, Stay with You Forever," Oz: Vol. 40. https://doi.org/10.4148/ 2378-5853.1572

This Article is brought to you for free and open access by New Prairie Press. It has been accepted for inclusion in Oz by an authorized administrator of New Prairie Press. For more information, please contact cads@k-state.edu. 
Driely S.

The photos I didn't take, wouldn't let me get out of bed today. They do this to me often. Every time I think I have developed a coping mechanism, they sneak up on me. The photos I did not take are so real in my vision, that they become an actual force-presence in my daily existence. I see them every damn day. And sooner or later, I feel them too. Their insistence hurts me so. And as much as I try and use them to my advantage, the photos I did not take haunt me forever

I know it sounds crazy, and trust me when I say it feels crazy. The minute I take a photograph I am over it. Just like that. They come out from me and they are free to go, and off they do go. But it is always the ones that got away that stay. And those stay with me forever. The ones when you know the sound of a shutter will ruin the moment, so you abstain. I don't always regret not taking those, but it doesn't mean they will haunt me any less afterwards. I call these my friendly ghosts. They often visit me when I am alone and sometimes I allow myself to indulge in their company. I hold on to them like memories. Just close enough so I can contemplate their nostalgic value. And if I ruminate on them for the right amount of time, sometimes those photos I did not take help me make new ones. But they don't go away. And that is the part that really bothers me.

Unfortunately for me, not every photo I did not take, is that friendly. And somehow, regardless of their with their hauntings. I don't always understand how they become photos I did not take. I am always willing to give them my all and do whatever is necessary to be the vessel to my work. I gather it is exactly because they know this, that they haunt me. The work knows what it does to you, and you just have to let it do it; there is no way around it. I don't fight the photos, I let them have it their way. In fact, I go out of my way to make it as easy as possible for these imaginary photos to become real photos. I want nothing more than to have them out of my head and be free. I want them out in the world doing whatever it is that they are meant to do. But when I fail to take them, they punish me. They put me down and make me feel like I didn't give it my all. The photos I did not take, stay with me forever. They creep up my brain and make me feel like a failure. They also remind me constantly that I can do better. I have to do better. If I don't, I get another image stuck in my mind, suffocating me from the inside out. How come I wasn't ready when that moment unfolded? How dare I not anticipate my subject's reaction? How could the universe be so perverse in changing the light faster than I could change my settings? Why would an image present itself to me like that, just to refuse to be captured? I still see them all so vividly, and it angers me I am the only one that will ever see them like this. I can describe them, but it never does them justice. These photos are mine to keep, and they never cease to dawn on me, like a curse.
The worst are the photos I did not take for some reason out of my control. I would give anything in the world to make myself free of those. Because the photos I could not take, stay with me forever. And it is so unfair they get to haunt me this way, when I fought so hard to birth them out. They exist in my head and in my head only. My inability to flesh them out as I see them, constantly puts me on the brink of insanity. And that hurts. So I fight people for them. I don't care if they might cost me relationships or all the money I have. It could mean not eating for two or three days, but when I take them, they fill my every void. I have come to learn that, the hunger for beauty is worth starving yourself for. But all the times someone stood in the way of my vision, or compromised my ideas, anytime something made it so I could not take my picture, the photos I could not take stayed and possessed me. They tied me down to my bed like they did today. They are so ingrained in my brain that I have no option but to argue their way, within the best of my abilities. Anything I can do or say to have someone just let me take my fucking photo. I make a little prayer to all my patron saints: help me persuade their trust with my honesty, let their egos not blind them from seeing my raw passion, may my genuine quest for substance be convincing enough. Anything but dull, boring, and pretentious. Or worst, having to deal with one more image stuck in my fucking head without a place to go. When the art gods fail me, the photos I could not take, will haunt me twice as ever. And I can't seem to help myself on feeling like I could have tried a little harder to give them life.

On the other hand, I have slowly started to make peace with the photos I neglected to take, despite the fact they will stay with me forever. They still haunt me in many ways, only now they show themselves to me as tests of my endurance. In my early twenties, I lost this little home I'd built. It was the first place I made for myself in America and was able to call a home. It was my self-made shelter, with all the things and books and movies and records that protected me from the world. And while I did take some photos there, it was mostly the photos that it didn't allow me to take, that ultimately pushed me to leave. The photos I neglected to take because I chose to give myself to someone and to a place, rather than my art, are the ones that haunt me the most. The irony being, that every neglected frame would burn me up in flames to become the very fire that sets me up in motion to chase new photos. Because of these photos, I have lost jobs, relatives, loved ones, and certainly my mind. But somehow, losing all of these things made it so I never lost myself. I do have hopes that the photos I neglected to take, will at least let me die in my own footsteps.

Until then, the photos I do not take, will stay with me forever.

Your talent is your curse.

There is no other way. And there never was. 


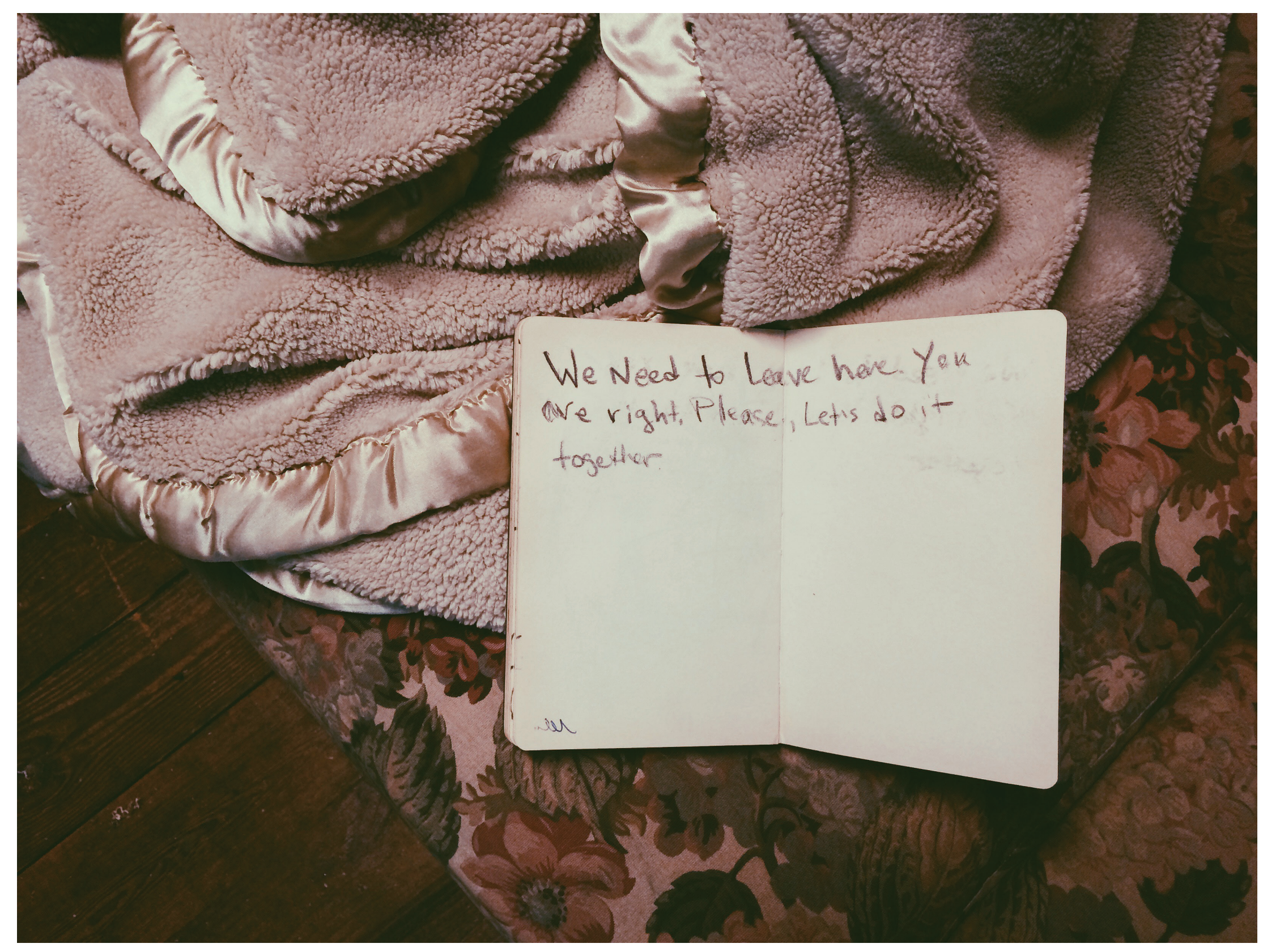

